Article

\title{
Capital Structure as a Mediating Factor in the Relationship between Uncertainty, CSR, Stakeholder Interest and Financial Performance
}

\author{
Ahmed Imran Hunjra ${ }^{1, * \mathbb{C}}$, Peter Verhoeven ${ }^{2}$ and Qasim Zureigat ${ }^{3}$ \\ 1 University Institute of Management Sciences, PMAS-Arid Agriculture University, \\ Rawalpindi 46000, Pakistan \\ 2 School of Economics and Finance, QUT Business School, Brisbane 4000, Australia; \\ peter.verhoeven@qut.edu.au \\ 3 Sulaiman AlRajhi School of Business, Sulaiman AlRajhi University, \\ Al Bukayriyah 51941, Al Qassim Province, Saudi Arabia; q.zureigat@sr.edu.sa \\ * Correspondence: ahmedhunjra@gmail.com
}

Received: 26 March 2020; Accepted: 2 June 2020; Published: 5 June 2020

\begin{abstract}
We examine the mediating role of capital structure in the perceived relationship of uncertainty, corporate social responsibility (CSR), stakeholder interest and financial performance. We collect data through questionnaires, and survey the Chief Financial Officers (CFOs) of the service sector of Pakistan. We apply Structure Equation Modeling (SEM) for data analysis. We find that CFOs perceive uncertainty, CSR and stakeholder interest to have both direct and indirect impacts on financial performance. In particular, we find evidence of the mediating effect of capital structure in the relationship. Our findings imply that firms screen out uncertain situations while making capital structure decision and pursuing CSR-related activities.
\end{abstract}

Keywords: capital structure; uncertainty; CSR; stakeholder interest; financial performance

\section{Introduction}

Capital structure is about how a firm finances its overall operations and growth using different sources of financing. It is one of the principle considerations in the firm's financing policy given the crucial role it plays in corporate performance. In the literature, the determinants of the capital structure of firms are widely discussed (Capon et al. 1990). Being forward-looking, Chatterjee et al. (2003) reveal that uncertainty has a major influence on the capital structure decision-making process adopted by finance executives. According to stakeholder theory, stakeholders also have a link with financing decision-making. For example, Bae et al. (2019) document that corporate social responsibility (CSR) reduces losses in market share when firms are highly leveraged, helping in keeping customers and guarding against rivals' predation. Their findings support the stakeholder value maximization view of CSR (Graves and Waddock 2000; Boubaker and Nguyen 2014).

In this paper, we examine the mediating role of capital structure in the relationship between uncertainty, CSR, stakeholder interest and financial performance. We focus on the emerging market of Pakistan, where we believe such an examination is worthy due to the illiquidity of its financial markets, its high business uncertainty, and it being a place where CSR-related considerations (thinking/practices) are relatively new. We believe that a better understanding of the perceived links may help corporations to improve their capital structure so as to maximize financial performance.

Based on survey data from Chief Financial Officers (CFOs) of the service sector of Pakistan and Structure Equation Modeling (SEM), we find that capital structure plays a mediating role between uncertainty, CSR, stakeholder interest and financial performance. Firms screen out uncertain situations 
while making capital structure decision and pursuing CSR-related activities. Our work contributes to the emerging market literature on factors that drive financial performance, and attempts to examine capital structure as the mediating factor.

The paper is organized as follows. Section 2 provides the literature review and development of the hypotheses; Section 3 discusses the identification method, the variables and data used in the empirical analysis; Section 4 represents the empirical results, followed by a conclusion in Section 5.

\section{Literature Review and Hypotheses Development}

Lawrence and Lorsch (1967) explain that uncertainty arises due to a lack of understanding about the outcomes of a decision, i.e., how decisions affect the financial performance of firms. In this situation, a greater focus on the survival of the firm is paramount. Firms face uncertainty not only with respect to the future return on the project but also with respect to their ability to finance their investments (Boyle and Guthrie 2003). Uncertainty increases the costs to firms, through the adjustment of capital, fluctuations in demand, variation in stock prices, and the volatility in political and economic factors (Jensen and Meckling 1976). For example, management may need to retain more of their earnings to lower vulnerability in uncertain situations. Khandwalla (1976) explains that corporate strategies in uncertain business environments are more innovative and proactive. Swamidass and Newell (1987), and Khatri and D'Netto (1997), point out the negative relation between uncertainty and the financial performance of firms. When management perceives high environmental uncertainty, it may lead to a devaluation of their skills in developing effective strategic plans for their firm, which negatively affects financial performance. Barnard (1938) suggests that firms survive based on the ability of their managers to keep the equilibrium between internal operations and the external environment. Keeping all this in view, we propose the following hypothesis:

Hypothesis 1 (H1). Uncertainty negatively affects financial performance.

Jamali and Karam (2018) perform a content analysis of 452 CSR articles for the period 1990-2015. They identify a number of key attributes of CSR thinking in developing countries, including nuanced forms of CSR expressions and the varied scope of developmental and detrimental CSR consequences. They conclude that CSR is invariably contextualized and shaped by multi-level factors embedded within formal and informal governance systems. In particular, the nuanced forms of CSR in developing countries are invariably contextualized and locally shaped by multi-level factors and actors, embedded within wider formal and informal governance systems.

There are two major arguments for investment in CSR-related activities. One is legitimation (social/moral/relational), and the other is corporate efficiency (instrumental) (Aguilera et al. 2007). CSR may not have a strong relation with financial performance if firms only engage in CSR practices in response to regulative, cognitive and normative institutional forces, in order to gain and improve corporate legitimacy (Ntim and Soobaroyen 2013). Friedman (1970) argues that firms that invest more in CSR are bearing higher costs, and this may put them at an economic disadvantage in comparison to those firms that are less socially responsible. In contrast, Jensen and Meckling (1976) are of the view that involvement in CSR can improve efficiency and financial performance by minimizing information asymmetry. Suchman (1995) suggests that investment in CSR, by facilitating compliance with social norms so as to legitimize the business operations, may allow them to access critical resources. Donaldson and Preston (1995) argue that addressing the needs of stakeholders, including employees, customers and governments, may lead to improved financial performance by reducing customer boycotts, labor frictions and political costs (taxation, regulation, litigation and nationalization). Based on the arguments above, we propose the following:

Hypothesis 2 (H2). CSR positively affects financial performance. 
The hypothesis of social impact is based on the stakeholder theory, which suggests that the value creation at the stakeholder's end is the foremost long-term goal of any firm (Freeman 1984). If all claims of stakeholders are considered, it should lead to better financial performance. The most important task of managers is maintaining an environment in which all stakeholders can optimally deliver their skills and knowledge to the firm (Freeman et al. 2004). Sen et al. (2006) note that CSR awareness relates to positive stakeholder reactions towards the financial performance of the firm. Du et al. (2011) are of the view that, by engaging in CSR-related activities, firms not only generate favorable stakeholder attitudes and more support for their behaviors (e.g., purchase, seeking employment, investing in the firm), but also, in the long-run, build a strong corporate image, strengthen the stakeholder-firm relationship and enhance stakeholder advocacy behaviors. Firms which consider the interests and opinions of stakeholders have good output in financial terms in the near future. Hence, the interests of all stakeholders should be considered in management decision-making; if the firm fails to do this, it may lose the investments made by their stakeholders (Lorca and García-Diez 2004). Therefore, to build a positive and effective network with all stakeholders is a necessary condition for the survival of the firm (Post et al. 2002). Thus,

Hypothesis 3 (H3). Stakeholder interest positively affects financial performance.

Capital structure is a major corporate decision, which concerns itself with the financing mix of the firm. It involves decisions regarding whether to use retained earnings, external debt or equity to fund the firm's operations. The Modigliani-Miller (MM) theorem, agency cost theory, pecking order theory and static trade-off theory are important theories of capital structure. When the capital of the firm comprises only of equity, all the earnings after tax belong to the shareholders of the firm. When the level of debt increases, creditors are entitled to an increasing share of the profits. As per the trade-off theory of capital structure, firms can attain the optimal level of capital structure by managing their debt and equity levels while keeping the balance between the tax benefits and costs of financial distress (Hackbarth et al. 2007). In their second paper on capital structure, Modigliani and Miller (1963) propose that firm value is positively related to leverage, based on the tax deductibility of payments of interest available at the firm level. In the theory of capital structure, Harris and Raviv (1991) argue that for both managers and shareholders, capital structure is associated with the trade-off between liquidation cost and liquidation gain. Thus, reasons that firms have a greater portion of debt in their capital structure than is appropriate is because they want to acquire greater advantages for shareholders and managers or because they are not giving enough importance to bankruptcy cost.

In the three decades after MM's second paper, extensive academic effort has been invested in recognizing the costs of debt financing, even though direct cost of bankruptcy is perhaps small. Potentially vital aspects include personal tax, corporate control, asymmetric information, input/product market exchanges and agency cost concerns. Early empirical findings on the trade-off theory provide mixed outcome (Bradley et al. 1984; Myers 1984). Studies investigating the response of capital structure to variations in tax exposure present evidence in support of the trade-off theory (MacKie-Mason 1990; Givoly et al. 1992). Indeed, Welch (2004) shows that high leverage leads to poorer stock price performance. Margaritis and Psillaki (2010) analyze the association between firm performance, equity ownership and capital structure, using a sample of French manufacturing firms. They find evidence consistent with the agency cost hypothesis, in that higher leverage (debt monitoring) is associated with much improved efficiency. Based on the arguments presented above, we propose the following:

\section{Hypothesis 4 (H4). Capital structure positively affects financial performance.}

Whilst financing decisions are important, under perfect capital market assumptions, a firm's market value and investment plan are assumed to be independent of its capital structure or the debt scheme (Modigliani and Miller 1958). The asset substitution problem (Galai and Masulis 1976; Jensen and Meckling 1976) states that high uncertainty leads to distressed firms with an incentive to engage 
in higher levels of investment. The notion of his model is that financially distressed firms shift their losses from equity holders to debt holder. That is, financially distressed firms have the opportunity to invest when uncertainty is high, because losses due to bad outcomes are predominantly carried by its debt holders; if the outcomes are favorable, then shareholders enjoy the gains. In simple words, if there is high uncertainty, there might be chances to earn more profit, since shareholder can enjoy the rewards if circumstances favor them, but they do not have to bear the cost if things go in the opposite direction. Eisdorfer (2008) provides empirical results supporting this proposition. In the literature, the impact of uncertainty on capital structure is widely discussed. It is well documented that firms use less debt during times of high uncertainty (Caglayan and Rashid 2014; Chow et al. 2018; Rashid 2013; Baum et al. 2009; Levy and Hennessy 2007). We propose the following:

Hypothesis 5 (H5). Uncertainty negatively affects capital structure.

Hypothesis 6 (H6). Uncertainty and financial performance are mediated by capital structure.

The relation between CSR and capital structure has been examined by a number of studies (Bae et al. 2011; Girerd-Potin et al. 2011; Verwijmeren and Derwall 2010). These studies develop a model aligned with the trade-off theory of capital structure. They discuss the trade-off between the cost (bankruptcy cost) and benefits of debt (tax gains) on the one hand, and the cost and benefit of equity on the other. Based on the assumption that firms can freely choose the level of investment in CSR-related activities, they argue that a lower cost of equity is aligned with CSR firms as compared to socially irresponsible firms. Verwijmeren and Derwall (2010) present evidence that suggests that firms with leading track records in employee well-being operate with lower debt ratios. As such, they have significantly lower likelihood of bankruptcy. Further, firms with better employee track record have higher credit ratings, even when controlling for differences in firm leverage. Bae et al. (2011) provide insights into the potentially important role of CSR in reducing the costs of high leverage due to a firm's conflicts with its stakeholders, such as customers and competitors. Observing the relation between cost of capital and environmental performance, Sharfman and Fernando (2008) note that companies with good environmental performance, in the face of higher cost of debt, also have a higher debt to equity ratio. El Ghoul et al. (2011) note that unionized firms have a lower cost of debt when compared to non-unionized companies. Arguably shareholders depriving bondholders is less likely to occur because of union pressure. Thus, we propose the following:

Hypothesis 7 (H7). CSR positively affects capital structure.

Hypothesis 8 (H8). CSR and financial performance are mediated by capital structure.

Titman (1984) is the first to argue that stakeholder interest regarding firm-specific investments influences the financing decisions of the firm, with stakeholders (the customers, workers and suppliers as principals) facing switching costs if somehow the firm is liquidated. Thus, by serving as a bonding mechanism, capital structure may be able to control the incentive or conflict problem of this relationship. The appropriate selection of capital structure ensures that incentives are aligned so that firms implement the ex-ante value-maximizing liquidation policy. Several empirical studies provide results consistent with the theory. For example, Titman and Wessels (1988) find that debt levels are negatively related to the "uniqueness" of a firm's line of business. Barton et al. (1989) show that firms with higher levels of net organizational capital have fundamentally less debt. Banerjee et al. (2008) reveal that firms in bilateral relationships are likely to produce or procure unique products, with such firms likely to maintain lower leverage. Consistent with a bargaining role for debt, Kale and Shahrur (2007) find a positive relation between firm debt level and the degree of concentration in supplier/customer industries. The literature also shows that stakeholders impact the compensation plans for the CEO's (Arora and Alam 2005) and the firms' earnings management (Raman and Shahrur 2008). In sum, whilst making capital structure 
decisions, it is necessary for finance managers to first formulate and then implement the processes which are satisfactory for all, including those interest groups which have a stake in the business. In this regard, it is important to manage and integrate into the decision-making the relationship of the firm with all its stakeholders, including suppliers, customers, employees, communities and other groups, so as to maximise the success of the firm. Thus, we propose the following:

Hypothesis 9 (H9). Stakeholder interest positively affects capital structure.

Hypothesis 10 (H10). Stakeholder interest and financial performance are mediated by capital structure.

Figure 1 summarizes the conceptual framework.

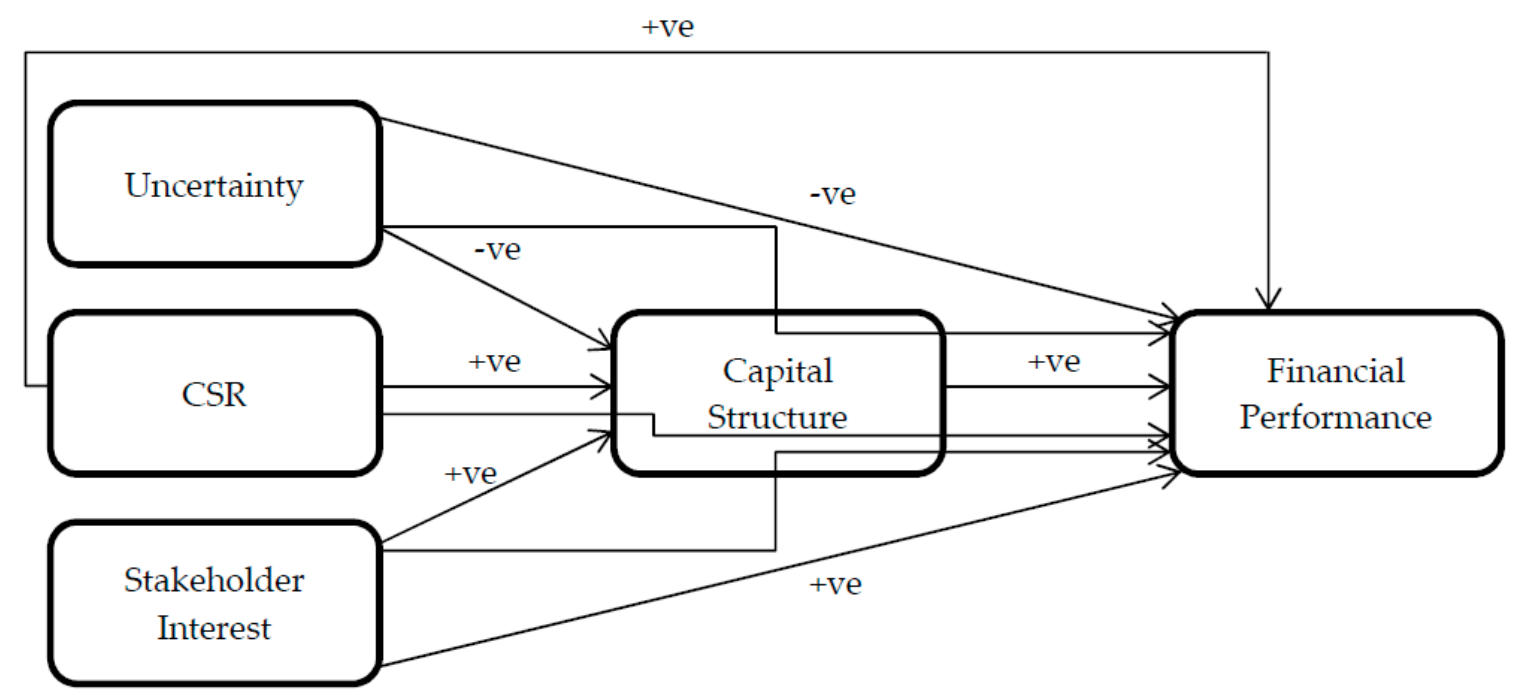

Figure 1. Conceptual framework. Note: CSR = Corporate Social Responsibility.

\section{Research Methodology}

We target the Chief Financial Officers (CFOs) of firms from the three leading industries in the services sector (Telecommunication, Banking and Insurance) listed at the Pakistan Stock Exchange (PXE) during 2012-2013. We use the profile, reference and telephone number of the firm for financial personnel identification. We use a close-ended questionnaire for data collection (see Table A1 in Appendix A). We distribute the questionnaire among $84 \mathrm{CFOs}$ and receive $61(72 \%)$ completed questionnaires for further analysis.

We use a five-point Likert scale to measure the instruments. We employ confirmatory factor analysis (CFA) to check for measurement problems, as well as the reliability and validity of the instruments used. According to Steenkamp and Baumgartner (2000), CFA is a suitable approach in determining the strength (weak or strong) of latent variables.

The assessment of the structural model is not possible without testing discriminate validity (Kline 2005). The results of the goodness-of-fit tests are provided in Table 1. Reported are the comparative fit index (CFI), goodness-of-fit index (GFI), chi-square goodness-of-fit (CMIN/DF), root-mean-square error of approximation (RMSEA), adjusted goodness-of-fit index (AGFI), normed fit index (NFI) and Tucker-Lewis coefficient (TLI). The results show that the value of Chi-square/DF is between 3 and 5 , the threshold value for GFI, NFI, CFI, TLI is 0.90 or greater, and RMSEA is less than 0.08 ; all suggestive of a good model fit (Hair et al. 1998). 
Table 1. Goodness-of-fit tests.

\begin{tabular}{lcccc}
\hline \multicolumn{1}{c}{ (SR.) Variables } & Factors & Values & Factors & Values \\
\hline (I.) Uncertainty & Chi-square/df & 3.278 & RMSEA & 0.054 \\
& AGFI & 0.838 & GFI & 0.918 \\
& TLI & 0.896 & CFI & 0.932 \\
(II.) CSR & Chi-square/df & 3.911 & RMSEA & 0.052 \\
& AGFI & 0.817 & GFI & 0.911 \\
& TLI & 0.891 & CFI & 0.813 \\
(III.) Stakeholder Interest & Chi-square/df & 3.060 & RMSEA & 0.043 \\
& AGFI & 0.853 & GFI & 0.939 \\
& TLI & 0.904 & CFI & 0.916 \\
(IV.) Financial Performance & Chi-square/df & 4.199 & RMSEA & 0.059 \\
& AGFI & 0.744 & GFI & 0.907 \\
& TLI & 0.887 & CFI & 0.897 \\
(V.) Capital Structure & Chi-square/df & 3.062 & RMSEA & 0.057 \\
& AGFI & 0.851 & GFI & 0.945 \\
& TLI & 0.910 & CFI & 0.916 \\
\hline
\end{tabular}

Note: Reported are the comparative fit index (CFI), goodness-of-fit index (GFI), chi-square goodness-of-fit (CMIN/DF), root-mean-square error of approximation (RMSEA), adjusted goodness-of-fit index (AGFI), normed fit index (NFI) and Tucker-Lewis coefficient (TLI).

Table 2 displays the results for convergent validity - the standardized estimates, the average variance extracted (AVE) and construct reliability (CR)—obtained by applying the formula recommended by Fornell and Larcker (1981). According to Cua et al. (2001), items/questions that have a standardized factor loading above 0.50 can be considered valid instruments of the variable. According to Fornell and Larcker (1981), AVE values of 0.50 and above are suggestive of convergent validity. The values for CR should be greater than 0.70, as suggested by Fornell and Larcker (1981). We show that most of the items/questions are valid instruments of the latent variables; the values of AVE and CR, for all constructs, are above 0.50 and 0.70 , respectively. These results indicate the constructs of our study have convergent validity.

Table 2. Convergent validity tests.

\begin{tabular}{|c|c|c|c|}
\hline (SR.) Variables & Standard Estimate $(\geq 0.50)$ & AVE & CR \\
\hline (I.) Uncertainty & $\begin{array}{l}\text { I.1-11: } 0.73,0.67,0.71,0.66,0.78,0.88 \\
0.83,0.79,0.16,0.75,0.84,0.37,0.71\end{array}$ & 0.58 & 0.94 \\
\hline (II.) CSR—Risk and Market Opportunities & $\begin{array}{l}\text { II.1-3: } 0.31,0.23,0.38,0.42,0.25,0.69 \text {, } \\
0.83,0.87\end{array}$ & 0.64 & 0.84 \\
\hline CSR_Financial Growth & $\begin{array}{l}\text { II.4-12: } 0.26,0.56,0.74,0.76,0.79 \\
0.83,0.28,0.86,0.81,0.72,0.68,0.19\end{array}$ & 0.57 & 0.92 \\
\hline (III.) Stakeholder Interests & $\begin{array}{l}\text { III.1-9: 0.65, 0.95, 0.36, 0.74, 0.77, } \\
0.71,0.89,0.87,0.85,0.59\end{array}$ & 0.62 & 0.94 \\
\hline (IV.) Financial Performance & $\begin{array}{l}\text { IV.1-4: } 0.71,0.89,0.81,0.62,0.32, \\
0.15,0.29,0.46,0.41\end{array}$ & 0.58 & 0.85 \\
\hline (V.) Capital Structure Decision & V.1-3: $0.93,0.82,0.88$ & 0.58 & 0.91 \\
\hline Use of Alternative Sources of Financing & V.4-6: $0.90,0.76,0.65,0.61,0.82$ & 0.57 & 0.87 \\
\hline
\end{tabular}

Figure 2 displays the association amongst the variables used to compute discriminant and nomological validity. It also describes how much the variables are discriminant (different) from each other, and how much they are related to each other. The values on the paths represent the inter-construct correlation (IC) between the variables. We make the decision of discriminant and nomological validity on the basis of IC weights, reported in Table 3. 


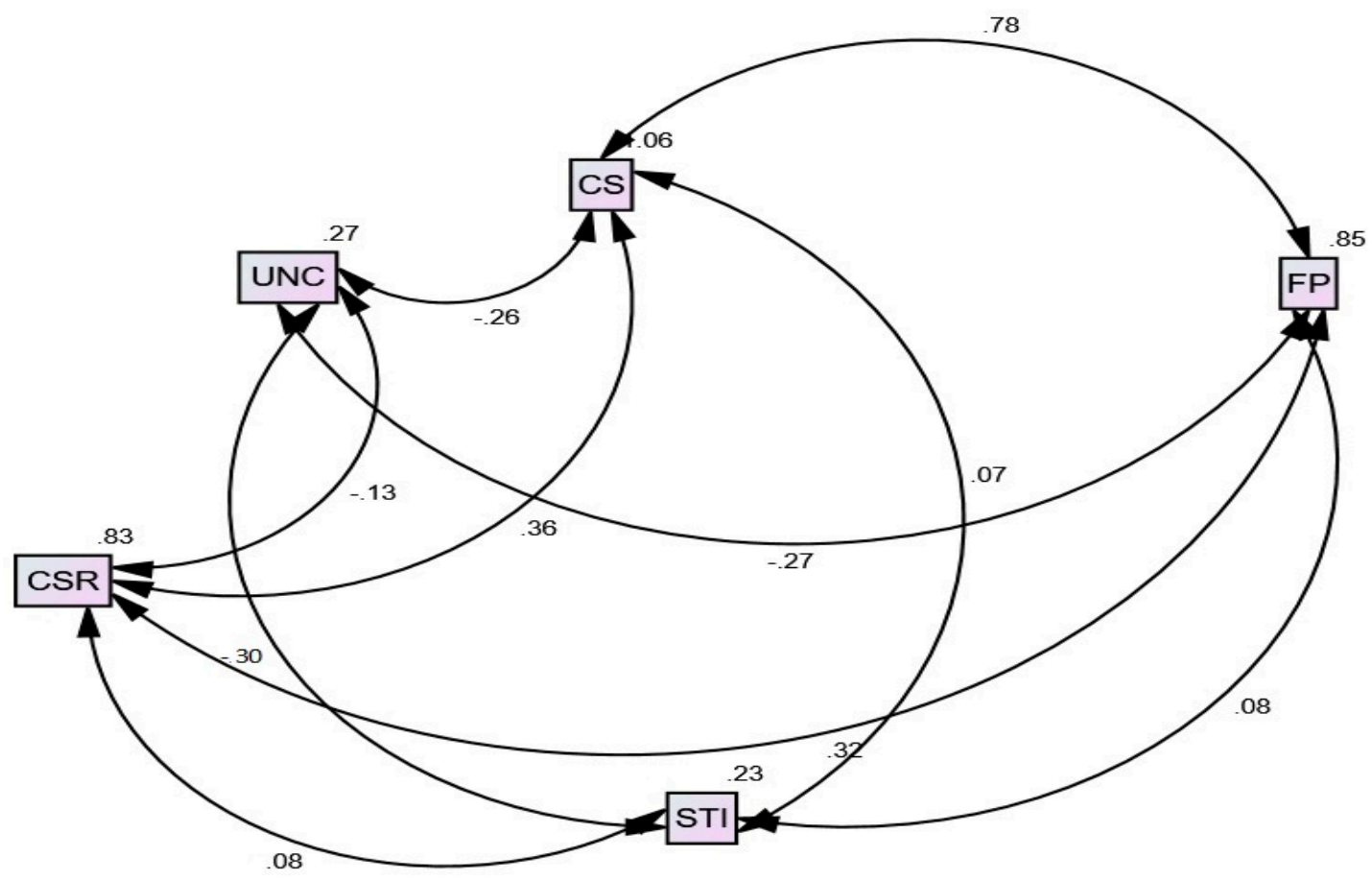

Figure 2. Covariance diagram. Note: UNC = Uncertainty, CSR = Corporate Social Responsibility, STI $=$ Stakeholder Interest, FP = Financial Performance and CS = Capital Structure.

Table 3. Discriminant and nomological validity tests.

\begin{tabular}{|c|c|c|c|c|c|c|c|c|}
\hline \multirow{3}{*}{$\begin{array}{c}\text { Construct } \\
\text { CSR } \\
\text { Uncertainty }\end{array}$} & \multicolumn{6}{|c|}{ Discriminant Validity } & \multicolumn{2}{|c|}{ Nomological Validity } \\
\hline & \multirow{2}{*}{$\begin{array}{c}\text { AVE } \\
0.64,0.57 \\
0.58\end{array}$} & \multicolumn{3}{|c|}{ Correlated Variables } & \multirow{2}{*}{$\begin{array}{c}\text { IC } \\
-0.131\end{array}$} & \multirow{2}{*}{$\begin{array}{c}\text { SIC } \\
0.017\end{array}$} & \multirow{2}{*}{$\begin{array}{c}p \text {-Value } \\
0.008\end{array}$} & \multirow{2}{*}{$\begin{array}{l}\text { Decision } \\
\text { Supported }\end{array}$} \\
\hline & & CSR & $<->$ & UNC & & & & \\
\hline $\begin{array}{c}\text { Uncertainty } \\
\text { Stakeholder Interest }\end{array}$ & $\begin{array}{l}0.58 \\
0.62\end{array}$ & UNC & $<->$ & STI & -0.302 & 0.091 & 0.000 & Supported \\
\hline $\begin{array}{l}\text { Uncertainty } \\
\text { Financial Performance }\end{array}$ & $\begin{array}{l}0.58 \\
0.58\end{array}$ & UNC & $<->$ & $\mathrm{FP}$ & -0.270 & 0.073 & 0.000 & Supported \\
\hline $\begin{array}{c}\text { Uncertainty } \\
\text { Capital Structure }\end{array}$ & $\begin{array}{c}0.58 \\
0.58,0.57\end{array}$ & UNC & $<->$ & CS & -0.264 & 0.070 & 0.000 & Supported \\
\hline $\begin{array}{c}\text { CSR } \\
\text { Stakeholder Interest }\end{array}$ & $\begin{array}{c}0.64,0.57 \\
0.62\end{array}$ & CSR & $<->$ & STI & 0.080 & 0.006 & 0.013 & Supported \\
\hline $\begin{array}{c}\text { CSR } \\
\text { Financial Performance }\end{array}$ & $\begin{array}{c}0.64,0.57 \\
0.58\end{array}$ & CSR & $<->$ & FP & 0.322 & 0.104 & 0.000 & Supported \\
\hline $\begin{array}{c}\text { CSR } \\
\text { Capital Structure }\end{array}$ & $\begin{array}{l}0.64,0.57 \\
0.58,0.57\end{array}$ & CSR & $<->$ & CS & 0.360 & 0.130 & 0.000 & Supported \\
\hline $\begin{array}{l}\text { Stakeholder Interest } \\
\text { Financial Performance }\end{array}$ & $\begin{array}{l}0.62 \\
0.58\end{array}$ & STI & $<->$ & FP & 0.081 & 0.007 & 0.013 & Supported \\
\hline $\begin{array}{l}\text { Stakeholder Interest } \\
\text { Capital Structure }\end{array}$ & $\begin{array}{c}0.62 \\
0.58,0.57\end{array}$ & STI & $<->$ & CS & 0.074 & 0.005 & 0.016 & Supported \\
\hline $\begin{array}{l}\text { Financial Performance } \\
\text { Capital Structure }\end{array}$ & $\begin{array}{c}0.58 \\
0.58,0.57\end{array}$ & FP & $<->$ & CS & 0.782 & 0.612 & 0.000 & Supported \\
\hline
\end{tabular}

Note: UNC = Uncertainty, CSR = Corporate Social Responsibility, STI = Stakeholder Interest, FP = Financial Performance and CS = Capital Structure.

According to Fornell and Larcker (1981), the AVE value of two correlated variables should be greater than the squared inter-construct correlation (SIC). We find that all the values of SICs in Table 3 are less than the AVE of two related constructs, suggesting discriminant validity. We use ICs, which show the logical relation between two variables, to check for nomological validity. This also confirms the direction of association $( \pm$ ) between two variables. In sum, we find that all the constructs/variables are logically interlinked with each other and are intuitive. The values of inter-construct correlation indicate there is significantly strong association between the constructs. 
Table 4 reports on the reliability of the data. Cronbach's Alpha is greater than 0.7 for all variables, suggesting that the instruments are reliable and that internal consistency exists (Hair et al. 1998). We apply a descriptive test to check for the normality of the data, whilst Pearson correlation is used to check for association between the variables. Furthermore, we calculate the variance inflating function (VIF) and tolerance (Tol) to diagnose potential multicollinearity problems. We employ one-way ANOVA to check for mean differences between the variables with respect to firm age.

Table 4. Variable sources and reliability.

\begin{tabular}{cccccc}
\hline Sr. No. & Variables & Source & Items & Valid Items & Cronbach's Alpha \\
\hline 1. & Uncertainty & Verbeeten (2006) & 13 & 11 & 0.864 \\
2. & CSR & Tyagi (2012) & 20 & 12 & 0.792 \\
3. & Stakeholder Interest & Elijido-Ten (2006) & 10 & 09 & 0.837 \\
4 & Financial Performance & Schulz et al. (2010) & 09 & 04 & 0.851 \\
5. & Capital Structure & McCaffery et al. (1997) & 09 & 08 & 0.916 \\
\hline
\end{tabular}

We employ structural equation modeling (SEM) for hypotheses testing. This technique captures the direct (without mediator) and indirect (with mediator, i.e., capital structure) effect of the independent variables (uncertainty, CSR and stakeholder interest) on financial performance. We check mediation between the independent and dependent variables using Hoyle and Smith (1994) procedure. We further test for partial or full mediation in the model. This procedure has two stages. In the first stage, we estimate the direct effect of the independent variables on the dependent variable. In the second stage, we estimate the indirect effect of the independent variables on the dependent variable through the mediating variable. If the relation between the dependent variable and the independent variable through the mediating variable is insignificant, this suggests full mediation. However, partial mediation exists when the relation is significant with decreasing coefficient (Hoyle and Smith 1994).

\section{Results}

The descriptive statistics are provided in Table 5. The mean values are large, implying that CFOs consider uncertainty, CSR, stakeholder interest and capital structure to be important factors for financial performance. The correlation coefficients between the variables suggest that there is no issue of multicollinearity.

Table 5. Descriptive and correlation analysis.

\begin{tabular}{cccccccc}
\hline Variables & Mean & St. Dev. & UNC & CSR & STI & FP & CS \\
\hline UNC & 3.849 & 0.712 & 1.00 & & & & \\
CSR & 4.179 & 0.516 & $-0.241^{*}$ & 1.00 & & & \\
STI & 3.901 & 0.491 & $-0.224^{*}$ & 0.221 & 1.00 & & \\
FP & 3.956 & 0.805 & $-0.536^{* *}$ & $0.336^{* *}$ & $0.253^{*}$ & 1.00 & \\
CS & 3.608 & 0.782 & $-0.453^{* *}$ & $0.314^{* *}$ & $0.225^{*}$ & $0.542 * *$ & 1.00 \\
\hline
\end{tabular}

Notes: ${ }^{*} \& * *$ imply significance at the $5 \%$ and $1 \%$ level, respectively.

Table 6 provides the one-way ANOVA results for the test of mean differences between the test variables and firm age. We find the mean values of the variables of interest are significantly different across firm age. As the firm matures, CFOs tend to give more weight to uncertainty when evaluating firm outcomes. We find similar results for CSR, increasing in importance as a factor in decision-making as the firm matures. Further, we find that younger firms are focused more on stakeholder interest when compared to older firms. Identifying stakeholder interest in the routine operations of the business is one of the key objectives of compliance (Mitchell et al. 1997; Freeman 1999). Finally, both young firms ( $<10$ years) and old firms ( $>30$ years) tend to be more concerned about their capital structure than firms of median age (10-30 years). 
Table 6. Mean differences in test variables with respect to firm age.

\begin{tabular}{|c|c|c|c|c|c|}
\hline Variables & Firm Age & $\mathbf{N}$ & Mean & F-Value & $p$-Value \\
\hline \multirow[t]{5}{*}{ Uncertainty } & $<10$ & 7 & 3.3429 & 4.688 & 0.008 \\
\hline & $10-20$ & 24 & 3.6472 & & \\
\hline & $21-30$ & 21 & 3.6222 & & \\
\hline & $>30$ & 9 & 3.7741 & & \\
\hline & Total & 61 & 3.9486 & & \\
\hline \multirow[t]{5}{*}{ CSR } & $<10$ & 7 & 2.8776 & 2.736 & 0.052 \\
\hline & $10-20$ & 24 & 2.8861 & & \\
\hline & $21-30$ & 21 & 3.4388 & & \\
\hline & $>30$ & 9 & 3.6429 & & \\
\hline & Total & 61 & 3.8792 & & \\
\hline \multirow[t]{5}{*}{ Stakeholder Interest } & $<10$ & 7 & 4.3129 & 4.201 & 0.009 \\
\hline & 10-20 & 24 & 3.9121 & & \\
\hline & $21-30$ & 21 & 3.6705 & & \\
\hline & $>30$ & 9 & 3.0878 & & \\
\hline & Total & 61 & 3.9008 & & \\
\hline \multirow[t]{5}{*}{ Financial Performance } & $<10$ & 7 & 3.4762 & 3.906 & 0.013 \\
\hline & 10-20 & 24 & 2.7569 & & \\
\hline & $21-30$ & 21 & 2.7143 & & \\
\hline & $>30$ & 9 & 3.6481 & & \\
\hline & Total & 61 & 3.9563 & & \\
\hline \multirow[t]{5}{*}{ Capital Structure } & $<10$ & 7 & 3.3016 & 4.863 & 0.004 \\
\hline & 10-20 & 24 & 2.3683 & & \\
\hline & $21-30$ & 21 & 2.3976 & & \\
\hline & $>30$ & 9 & 3.4938 & & \\
\hline & Total & 61 & 3.6515 & & \\
\hline
\end{tabular}

Table 7 shows the goodness-of-fit indexes as per Keramati et al. (2010), indicating that the statistical models describe well the set of observations.

Table 7. Model fit tests.

\begin{tabular}{cccc}
\hline \multicolumn{2}{c}{ Indexes of Fit of the Direct Model } & \multicolumn{2}{c}{ Indexes of Fit of Indirect Model } \\
\hline Factors & Values & Factors & Values \\
\hline Chi-square/df & 3.751 & Chi-square/df & 3.982 \\
NFI & 0.908 & NFI & 0.901 \\
GFI & 0.929 & GFI & 0.911 \\
AGFI & 0.873 & AGFI & 0.841 \\
TLI & 0.858 & TLI & 0.873 \\
CFI & 0.904 & CFI & 0.907 \\
RMSEA & 0.052 & RMSEA & 0.059 \\
\hline
\end{tabular}

Next, we estimate the regression coefficients of the model parameters for hypotheses testing. Figure 3 shows the direct effects of uncertainty, CSR, and stakeholder interest on financial performance, following the first step of SEM. The estimated regression weights of the direct effects are provided in Table 8. The results show that uncertainty negatively influences financial performance, whereas CSR and stakeholder interest positively influence financial performance. These results provide support for Hypotheses H1, H2 and H3. 


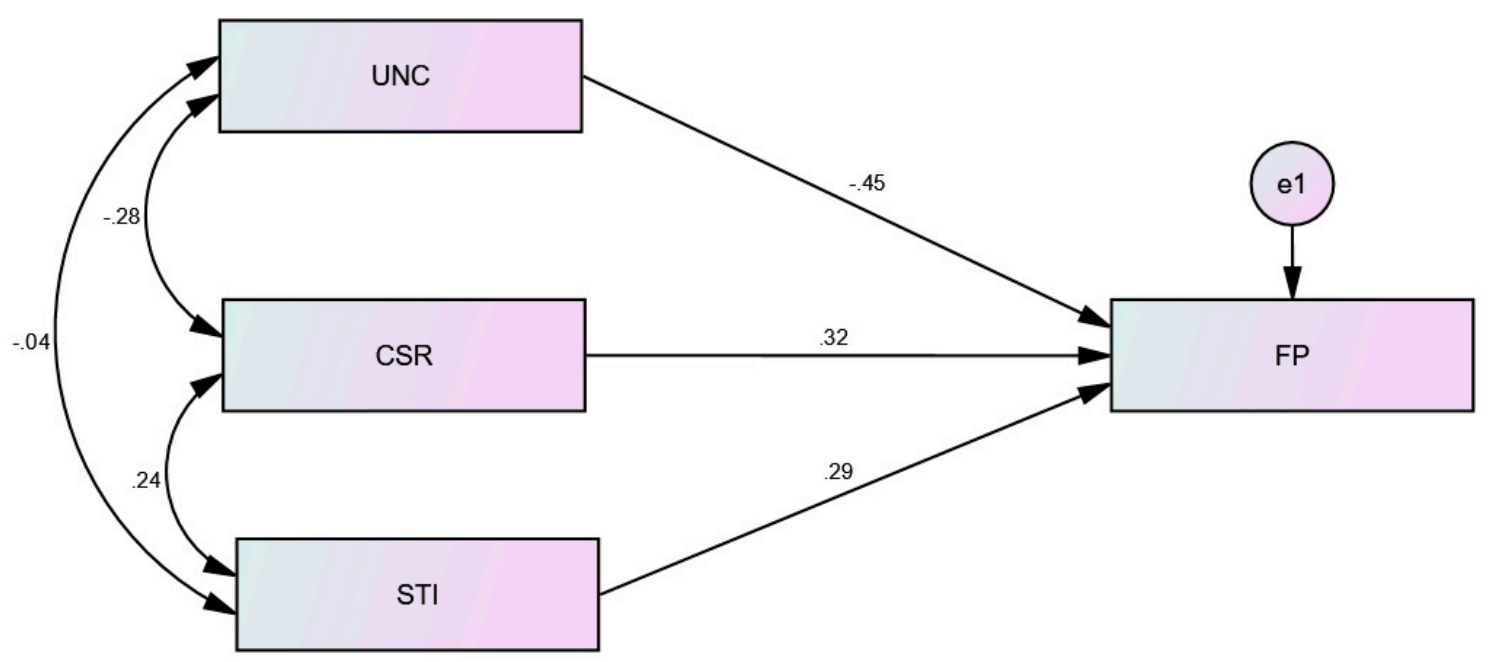

Figure 3. Direct effects.

Table 8. Regression weights (direct effects).

\begin{tabular}{lccccccc}
\hline \multicolumn{2}{c}{ Variables } & & Estimate & $p$-Value & Hypotheses Support & VIF & Tol. \\
\hline Financial Performance & $<-$ & Uncertainty & -0.454 & 0.000 & H1-supported & 1.137 & 0.880 \\
Financial Performance & $<-$ & CSR & 0.322 & 0.008 & H2-supported & 1.252 & 0.799 \\
Financial Performance & $<-$ & $\begin{array}{c}\text { Stakeholder } \\
\text { Interest }\end{array}$ & 0.293 & 0.014 & H3-supported & 1.114 & 0.898 \\
\hline
\end{tabular}

Note: VIF = Variance Inflation Factor, Tol. = Tolerance.

Figure 4 shows the results for the mediating role of capital structure, between the independent variables (uncertainty, CSR and stakeholder interest) and financial performance. The regression weights of the indirect effects of capital structure with uncertainty, CSR, stakeholder interest and financial performance are provided in Table 9. All coefficients are statistically significant and of the expected sign, as is consistent with hypotheses H4, H5, H7 and H9. Both regression models show no evidence of multicollinearity (VIF and Tol.).

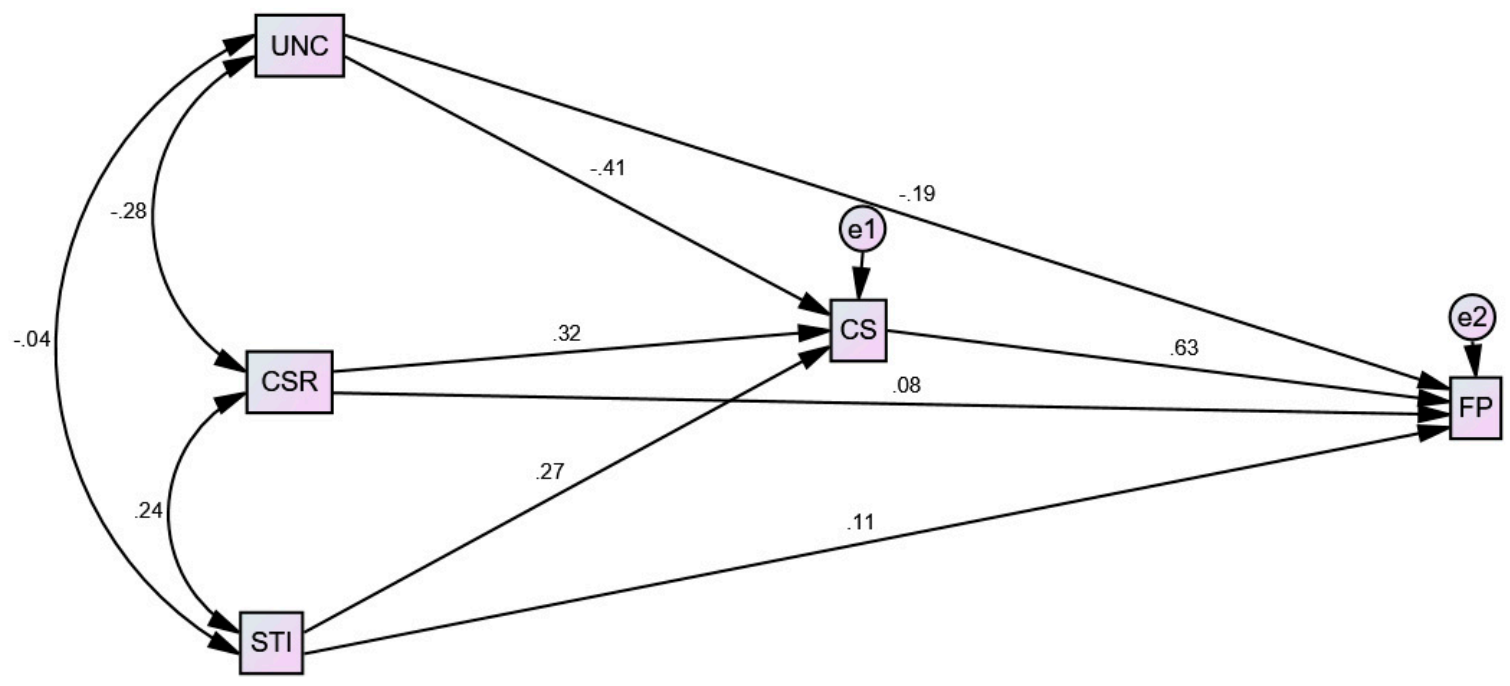

Figure 4. Indirect effects. 
Table 9. Regression weights (indirect effects).

\begin{tabular}{|c|c|c|c|c|c|c|c|}
\hline \multicolumn{3}{|c|}{ Variables } & \multirow{2}{*}{$\begin{array}{c}\text { Estimate } \\
0.632\end{array}$} & \multirow{2}{*}{$\frac{p \text {-Value }}{(0.000)}$} & \multirow{2}{*}{$\begin{array}{c}\text { Hypotheses Support } \\
\text { H4-supported }\end{array}$} & \multirow{2}{*}{$\frac{\text { VIF }}{1.513}$} & \multirow{2}{*}{$\begin{array}{r}\text { Tol. } \\
0.661\end{array}$} \\
\hline Financial Performance & $<-$ & Capital Structure & & & & & \\
\hline Capital Structure & $<-$ & Uncertainty & -0.413 & $(0.000)$ & H5-supported & 1.336 & 0.749 \\
\hline Capital Structure & $<-$ & CSR & 0.320 & $(0.014)$ & H7-supported & 1.252 & 0.799 \\
\hline Capital Structure & $<-$ & Stakeholder Interest & 0.274 & $(0.030)$ & H9-supported & 1.144 & 0.874 \\
\hline
\end{tabular}

In Table 10, we compare the direct and indirect effects, allowing us to make inferences about the mediating role of capital structure. We find that capital structure partially mediates between uncertainty and financial performance, supporting H6. Furthermore, we find capital structure fully mediates between CSR, stakeholder interest and financial performance, consistent with H8 and H10.

Table 10. Comparison of direct and indirect effects.

\begin{tabular}{llcccccc}
\hline \multirow{2}{*}{ Variables } & & \multicolumn{2}{c}{ Direct Effects } & \multicolumn{2}{c}{ Indirect Effects } & \multirow{2}{*}{ Hypotheses Support } \\
\cline { 3 - 6 } & & Estimate & $p$-Value & Estimate & $p$-Value & \\
\hline Financial Performance & $<-$ & Uncertainty & -0.454 & 0.000 & -0.193 & $(0.020)$ & H6-supported \\
Financial Performance & $<-$ & CSR & 0.322 & 0.008 & 0.081 & $(0.353)$ & H8-supported \\
Financial Performance & $<-$ & Stakeholder Interest & 0.293 & 0.014 & 0.108 & $(0.317)$ & H10-supported \\
\hline
\end{tabular}

The direct and indirect impacts of capital structure on financial performance identified in our study are consistent with the findings of Chatterjee et al. (2003) and Bae et al. (2011). Uncertainty has a direct impact on the financial performance of the firm. Further, there is a mediating effect of capital structure in the relationship between uncertainty, CSR, stakeholder interest and financial performance, supporting the results of Ittner and Larcker (2001). Further, we find evidence of a strong CSR effect when it comes to overall financial performance, thus supporting the study of Preston and O'Bannon (1997). We also find an economically significant relation between CSR and capital structure, as well as between stakeholder interests and financial performance. These findings support the findings of others (Freeman et al. 2004; Graves and Waddock 2000; Lorca and García-Diez 2004; Post et al. 2002). Incorporating capital structure as a mediator in the relation between uncertainty and financial performance results in a partially mediated impact, with uncertainty negatively influencing capital structure. This, in turn, positively affects financial performance, consistent with previous studies (Chay and Suh 2009). Capital structure acts as a complete mediating variable between CSR and financial performance, as well as between stakeholder interest and financial performance. It has an overall positive effect on financial performance. This is in line with the findings of Ahmad et al. (2012).

\section{Conclusions}

We examine the mediating role of capital structure in the relationship between uncertainty, CSR, stakeholder interest and financial performance. Our data are survey answers obtained from the Chief Financial Officers (CFOs) of 61 firms in three leading industries of the services sector, as listed at the Pakistan Stock Exchange (PXE) from 2012 to 2013. We use CFA to refine the instrument, and apply SEM to test the hypotheses. Our study makes important contributions to the corporate finance literature by augmenting our understanding of the perceived mechanism that governs the mediating role of capital structure, in the relationship between uncertainty, CSR, stakeholder interest and financial performance. In particular, we find that CFOs perceive uncertainty, CSR and stakeholder interest to have both direct and indirect impacts on financial performance. Firms screen out uncertain situations while making capital structure decision and pursuing CSR-related activities. Our findings imply that, to maximize firm performance, managers perceive they need to invest in CSR-related activities.

Our study opens new horizons for future research to include working capital as a mediating variable in the relationship between uncertainty, stakeholders' interest, CSR and financial performance. First, we encourage researchers from other countries to conduct similar survey analyses to examine whether the results are robust to different contexts. Second, a potentially fruitful avenue for future 
exploration is the use of both primary (perception based) and secondary data (outcome based) in investigating whether there is a gap between what CFOs perceive and what occurs. Finally, this study could be extended further by incorporating earnings management and treasury operations in the framework, as well as debt characteristics (including debt maturity, covenants and type).

Author Contributions: Conceptualization, A.I.H.; methodology, A.I.H.; software, A.I.H.; formal analysis, A.I.H.; data curation, Q.Z.; writing-original draft preparation, A.I.H.; writing-review and editing, P.V. and Q.Z.; supervision, P.V.; project administration, P.V. and Q.Z. All authors have read and agreed to the published version of the manuscript.

Funding: This research received no external funding.

Conflicts of Interest: The authors declare no conflict of interest.

\section{Appendix A}

Table A1. Questionnaire.

\begin{tabular}{|c|c|c|c|c|c|}
\hline \multirow{2}{*}{ SR \# } & \multirow{2}{*}{ Coding } & \multirow{2}{*}{ Variables } & \multicolumn{3}{|c|}{ Rating } \\
\hline & & & UN SUI N & SI & I \\
\hline I & & Uncertainty & & & \\
\hline 1. & UN1 & Market uncertainties & & & \\
\hline 2. & UN2 & Labor uncertainties & & & \\
\hline 3. & UN3 & Liability uncertainties & & & \\
\hline 4. & UN4 & Inflation uncertainties & & & \\
\hline 5. & UN5 & Interest rate uncertainties & & & \\
\hline 6. & UN6 & Exchange rate uncertainties & & & \\
\hline 7. & UN7 & Society related uncertainties & & & \\
\hline 8. & UN8 & Policy related uncertainties & & & \\
\hline 9. & UN9 & Competitive uncertainties & & & \\
\hline 10. & UN10 & Economic environment uncertainties & & & \\
\hline 11. & UN11 & Technological environment uncertainties & & & \\
\hline 12. & UN12 & Raw material uncertainties & & & \\
\hline 13. & UN13 & Regulatory uncertainties & & & \\
\hline II & & Corporate Social Responsibility (CSR) & & & \\
\hline (i). & & CSR_Risk and Market Opportunities & SD D & A & SA \\
\hline 1. & CSRR1 & $\begin{array}{l}\text { The financial risk profile of a firm has no influence on } \\
\text { CSR activities }\end{array}$ & & & \\
\hline 2. & CSRR2 & $\begin{array}{l}\text { It is rational to engage in CSR activities without any } \\
\text { concerns about the availability of free cash flow to fund } \\
\text { these activities }\end{array}$ & & & \\
\hline 3. & CSRR3 & $\begin{array}{l}\text { Entrance of new competitors or substitute products is } \\
\text { most likely to occur in sectors where CSR firms operate }\end{array}$ & & & \\
\hline
\end{tabular}


Table A1. Cont.

\begin{tabular}{|c|c|c|c|c|c|c|c|}
\hline \multirow{2}{*}{ SR \# } & \multirow{2}{*}{ Coding } & \multirow{2}{*}{ Variables } & \multicolumn{5}{|c|}{ Rating } \\
\hline & & & UN & SU & I $\mathbf{N}$ & SI & $\mathbf{I}$ \\
\hline II & & Corporate Social Responsibility (CSR) & & & & & \\
\hline (i). & & CSR_Risk and Market Opportunities & SD & D & $\mathbf{N}$ & A & SA \\
\hline 4. & CSRR4 & $\begin{array}{l}\text { If there are two identical firms, where one is socially } \\
\text { responsible and the other is not, the former would have } \\
\text { less downside risk and encounters fewer events } \\
\text { detrimental to its bottom line }\end{array}$ & & & & & \\
\hline 5. & CSRR5 & $\begin{array}{l}\text { Firms in a highly competitive environment engage in } \\
\text { CSR projects to gain competitive advantages }\end{array}$ & & & & & \\
\hline 6. & CSRR6 & $\begin{array}{l}\text { Attracting new partners for refinancing capital } \\
\text { requirement becomes easy for socially responsible firms. }\end{array}$ & & & & & \\
\hline 7. & CSRR7 & $\begin{array}{l}\text { Being socially responsible, it is easier to identify new } \\
\text { business opportunities and manage all market risks. }\end{array}$ & & & & & \\
\hline 8. & CSRR8 & $\begin{array}{l}\text { Firms with good social performance have more } \\
\text { opportunities for increased sales and new markets. }\end{array}$ & & & & & \\
\hline (ii). & & CSR_Financial Growth & SD & $\mathbf{D}$ & $\mathbf{N}$ & A & SA \\
\hline 9. & CSRFG1 & $\begin{array}{l}\text { Introducing CSR in financial practices does not facilitate } \\
\text { easy availability of trade credits or credit from other } \\
\text { sources, like financial institutions, for short-term } \\
\text { financing. }\end{array}$ & & & & & \\
\hline 10. & CSRFG2 & $\begin{array}{l}\text { CSR firms remain at par with conventional firms, while } \\
\text { raising capital for financing growth opportunities. }\end{array}$ & & & & & \\
\hline 11. & CSRFG3 & $\begin{array}{l}\text { In CSR firms, financial leverage is higher due to lower } \\
\text { cost of debt. }\end{array}$ & & & & & \\
\hline 12. & CSRFG4 & $\begin{array}{l}\text { CSR firms may lessen average cost of capital due to ease } \\
\text { of availability of sources of funds }\end{array}$ & & & & & \\
\hline 13. & CSRFG5 & $\begin{array}{l}\text { Investing in CSR activities is a kind of re-investment } \\
\text { where firm's retained earnings can be utilized. }\end{array}$ & & & & & \\
\hline 14. & CSRFG6 & $\begin{array}{l}\text { Firms practice ethical values due to competitive } \\
\text { pressures and their focus on short-term profits. }\end{array}$ & & & & & \\
\hline 15. & CSRFG7 & $\begin{array}{l}\text { Firms should not forgo short-run gains, even if it can } \\
\text { expect better returns in the long-run }\end{array}$ & & & & & \\
\hline 16. & CSRFG8 & $\begin{array}{l}\text { The net result of CSR expenditure translates into } \\
\text { profitability as this expenditure is an investment and not } \\
\text { an expenditure. }\end{array}$ & & & & & \\
\hline 17. & CSRFG9 & $\begin{array}{l}\text { Ethical practices, even at a financial cost, will enhance } \\
\text { financial performance and growth of businesses. }\end{array}$ & & & & & \\
\hline 18. & CSRFG10 & $\begin{array}{l}\text { CSR expenditure is a strategic decision of firms which } \\
\text { entitles them to tax relief. }\end{array}$ & & & & & \\
\hline 19. & CSRFG11 & $\begin{array}{l}\text { Firms should not reserve any amount of profit for socially } \\
\text { responsible activities }\end{array}$ & & & & & \\
\hline 20. & CSRFG12 & $\begin{array}{l}\text { Liberal participation in CSR activities could impact the } \\
\text { financial performance and competitiveness of the } \\
\text { business }\end{array}$ & & & & & \\
\hline
\end{tabular}


Table A1. Cont.

\begin{tabular}{|c|c|c|c|c|c|}
\hline \multirow{2}{*}{ SR \# } & \multirow{2}{*}{ Coding } & \multirow{2}{*}{ Variables } & \multicolumn{3}{|c|}{ Rating } \\
\hline & & & UN SUI N & SI & I \\
\hline III & & Stakeholder Interest & UN SUI N & SI & $\mathbf{I}$ \\
\hline 1. & SI1 & $\begin{array}{l}\text { Financial decisions are influenced by the major } \\
\text { shareholders ( }>5 \% \text { of shares outstanding) of the firm }\end{array}$ & & & \\
\hline 2. & SI2 & $\begin{array}{l}\text { Financial decisions are influenced by the minority } \\
\text { shareholders }(<5 \% \text { of shares outstanding) of the firm }\end{array}$ & & & \\
\hline 3. & SI3 & $\begin{array}{l}\text { Financial decisions are influenced by the long-term } \\
\text { creditors of the firm }\end{array}$ & & & \\
\hline 4. & SI 4 & $\begin{array}{l}\text { Financial decisions are influenced by relevant } \\
\text { government agencies }\end{array}$ & & & \\
\hline 5. & SI5 & $\begin{array}{l}\text { Financial decisions are influenced by the employees of } \\
\text { the firm. }\end{array}$ & & & \\
\hline 6. & SI6 & $\begin{array}{l}\text { Financial decisions are influenced by the customers of the } \\
\text { firm }\end{array}$ & & & \\
\hline 7. & SI7 & $\begin{array}{l}\text { Financial decisions are influenced by the suppliers of the } \\
\text { firm }\end{array}$ & & & \\
\hline 8. & SI8 & Financial decisions are influenced by the media & & & \\
\hline 9. & SI9 & $\begin{array}{l}\text { Financial decisions are influenced by special interest } \\
\text { groups, e.g., environmentalists }\end{array}$ & & & \\
\hline 10. & SI10 & $\begin{array}{l}\text { Financial decisions are influenced by the competitors of } \\
\text { the firm }\end{array}$ & & & \\
\hline IV & & Financial Performance & UN SUI N & SI & I \\
\hline 1. & FP1 & Long-run firm profitability & & & \\
\hline 2. & FP2 & Growth rate of sales and revenues & & & \\
\hline 3. & FP3 & Return on assets (ROA) & & & \\
\hline 4. & FP4 & Growth rate of return on assets (ROA) & & & \\
\hline 5. & FP5 & Market share & & & \\
\hline 6. & FP6 & Operational and cost efficiency & & & \\
\hline 7. & FP7 & Productivity & & & \\
\hline 8. & FP8 & Level of return on sales & & & \\
\hline 9. & FP9 & Growth rate of return on sales & & & \\
\hline $\mathbf{V}$ & & Capital Structure Decision & SD $\mathrm{D} \quad \mathrm{N}$ & A & SA \\
\hline 1. & CS1 & $\begin{array}{l}\text { The balance between long-term debt and equity has a } \\
\text { significant impact on firm value }\end{array}$ & & & \\
\hline 2. & CS2 & Firms should pursue a target debt to equity ratio & & & \\
\hline 3. & CS3 & $\begin{array}{l}\text { Firms should leave some of its debt financing capacity } \\
\text { unused to provide financial slack }\end{array}$ & & & \\
\hline 4. & CS4 & $\begin{array}{l}\text { Firms that experience financial distress have a capital } \\
\text { structure that has an over-reliance on the use of } \\
\text { long-term debt capital }\end{array}$ & & & \\
\hline
\end{tabular}


Table A1. Cont.

\begin{tabular}{|c|c|c|c|c|c|}
\hline \multirow{2}{*}{ SR \# } & \multirow{2}{*}{ Coding } & \multirow{2}{*}{ Variables } & \multicolumn{3}{|c|}{ Rating } \\
\hline & & & UN SUI N & SI & I \\
\hline & & Use of Alternative Sources of Financing & UN SUI N & SI & I \\
\hline 5. & CSASF1 & Short-term bank loans & & & \\
\hline 6. & CSASF2 & Long-term debt & & & \\
\hline 7. & CSASF3 & Equity rights issue & & & \\
\hline 8. & CSASF4 & New equity issues & & & \\
\hline 9. & CSASF5 & Retained earnings & & & \\
\hline
\end{tabular}

\section{References}

Aguilera, Ruth V., Deborah E. Rupp, Cynthia A. Williams, and Jyoti Ganapathi. 2007. Putting the S back in corporate social responsibility: A multilevel theory of social change in organizations. Academy of Management Review 32: 836-63. [CrossRef]

Ahmad, Zuraidah, Norhasniza Mohd Hasan Abdullah, and Shashazrina Roslan. 2012. Capital structure effect on firm performance: Focusing on consumers and industrials sectors on Malaysian firms. International Review of Business Research Papers 8: 137-55.

Arora, Alka, and Pervaiz Alam. 2005. CEO compensation and stakeholder claims. Contemporary Accounting Research 22: 519-47. [CrossRef]

Bae, Kee-Hong, Jun-Koo Kang, and Jin Wang. 2011. Employee treatment and firm leverage: A test of the stakeholder theory of capital structure. Journal of Financial Economics 100: 130-53. [CrossRef]

Bae, Kee-Hong, Sadok El Ghoul, Omrane Guedhami, Chuck CY Kwok, and Ying Zheng. 2019. Does corporate social responsibility reduce the costs of high leverage? Evidence from capital structure and product market interactions. Journal of Banking $\mathcal{E}$ Finance 100: 135-50. [CrossRef]

Banerjee, Shantanu, Sudipto Dasgupta, and Yungsan Kim. 2008. Buyer-supplier relationships and the stakeholder theory of capital structure. Journal of Finance 63: 2507-52. [CrossRef]

Barnard, Chester Irving. 1938. The Functions of the Executive. Cambridge: Harvard University Press, p. 376.

Barton, Sidney L., Ned C. Hill, and Srinivasan Sundaram. 1989. An empirical test of stakeholder theory predictions of capital structure. Financial Management 18: 36-44. [CrossRef]

Baum, Christopher F., Andreas Stephan, and Oleksandr Talavera. 2009. The effects of uncertainty on the leverage of nonfinancial firms. Economic Inquiry 47: 216-25. [CrossRef]

Boubaker, Sabri, and Duc Khuong Nguyen. 2014. Corporate Governance and Corporate Social Responsibility: Emerging Markets Focus. Singapore: World Scientific.

Boyle, Glenn W., and Graeme A. Guthrie. 2003. Investment, uncertainty, and liquidity. Journal of Finance 58: 2143-66. [CrossRef]

Bradley, Michael, Gregg A. Jarrell, and E. Han Kim. 1984. On the existence of an optimal capital structure: Theory and evidence. Journal of Finance 39: 857-78. [CrossRef]

Caglayan, Mustafa, and Abdul Rashid. 2014. The response of firms' leverage to risk: Evidence from UK public versus nonpublic manufacturing firms. Economic Inquiry 52: 341-63. [CrossRef]

Capon, Noel, John U. Farley, and Scott Hoenig. 1990. Determinants of financial performance: A meta-analysis. Management Science 36: 1143-59. [CrossRef]

Chatterjee, Sayan, Robert M. Wiseman, Avi Fiegenbaum, and Cynthia E. Devers. 2003. Integrating behavioural and economic concepts of risk into strategic management: The twain shall meet. Long Range Planning 36: 61-79. [CrossRef]

Chay, Jong-Bom, and Jungwon Suh. 2009. Payout policy and cash-flow uncertainty. Journal of Financial Economics 93: 88-107. [CrossRef] 
Chow, Yee Peng, Junaina Muhammad, A. N. Bany-Ariffin, and Fan Fah Cheng. 2018. Macroeconomic uncertainty, corporate governance and corporate capital structure. International Journal of Managerial Finance 14: 301-32. [CrossRef]

Cua, Kristy O., Kathleen E. McKone, and Roger G. Schroeder. 2001. Relationships between implementation of TQM, JIT, and TPM and manufacturing performance. Journal of Operations Management 19: 675-94. [CrossRef]

Donaldson, Thomas, and Lee E. Preston. 1995. The stakeholder theory of the corporation: Concepts, evidence, and implications. Academy of Management Review 20: 65-91. [CrossRef]

Du, Shuili, Chitra Bhanu Bhattacharya, and Sankar Sen. 2011. Corporate social responsibility and competitive advantage: Overcoming the trust barrier. Management Science 57: 1528-45. [CrossRef]

Eisdorfer, Assaf. 2008. Empirical evidence of risk shifting in financially distressed firms. Journal of Finance 63: 609-37. [CrossRef]

El Ghoul, Sadok, Omrane Guedhami, Chuck CY Kwok, and Dev R. Mishra. 2011. Does corporate social responsibility affect the cost of capital? Journal of Banking $\mathcal{E}$ Finance 35: 2388-406. [CrossRef]

Elijido-Ten, Evangeline. 2006. Extending the Application of Stakeholder Theory to Malaysian Corporate Environmental Disclosures. Kuching: Faculty of Business and Enterprise, Swinburne University of Technology.

Fornell, Claes, and David F. Larcker. 1981. Evaluating structural equation models with unobservable variables and measurement error. Journal of Marketing Research 18: 39-50. [CrossRef]

Freeman, R. Edward. 1984. Strategic Management: A Stakeholder Approach. Boston: Pitman.

Freeman, R. Edward. 1999. Divergent stakeholder theory. Academy of Management Review 24: 233-36. [CrossRef]

Freeman, R. Edward, Andrew C. Wicks, and Bidhan Parmar. 2004. Stakeholder theory and "the corporate objective revisited". Organization Science 15: 364-69. [CrossRef]

Friedman, Milton. 1970. A Friedman doctrine: The social responsibility of business is to increase its profits. New York Times Magazine 13: 32-33.

Galai, Dan, and Ronald W. Masulis. 1976. The option pricing model and the risk factor of stock. Journal of Financial Economics 3: 53-81. [CrossRef]

Girerd-Potin, Isabelle, Sonia Jimenez-Garces, and Pascal Louvet. 2011. The link between social rating and financial capital structure. Finance 32: 9-52. [CrossRef]

Givoly, Dan, Carla Hayn, Aharon R. Ofer, and Oded Sarig. 1992. Taxes and capital structure: Evidence from firms' response to the Tax Reform Act of 1986. Review of Financial Studies 5: 331-55. [CrossRef]

Graves, Samuel B., and Sandra A. Waddock. 2000. Beyond Built to Last. Stakeholder Relations in "Built-to-Last" Companies. Business and Society Review 105: 393-18. [CrossRef]

Hackbarth, Dirk, Christopher A. Hennessy, and Hayne E. Leland. 2007. Can the trade-off theory explain debt structure? Review of Financial Studies 20: 1389-428. [CrossRef]

Hair, Joseph F., William C. Black, Barry J. Babin, Rolph E. Anderson, and Ronald L. Tatham. 1998. Multivariate Data Analysis, 5th ed. Upper Saddle River: Prentice hall.

Harris, Milton, and Artur Raviv. 1991. The theory of capital structure. Journal of Finance 46: 297-55. [CrossRef]

Hoyle, Rick H., and Gregory T. Smith. 1994. Formulating clinical research hypotheses as structural equation models: A conceptual overview. Journal of Consulting and Clinical Psychology 62: 429-40. [CrossRef] [PubMed]

Ittner, Christopher D., and David F. Larcker. 2001. Assessing empirical research in managerial accounting: A value-based management perspective. Journal of Accounting and Economics 32: 349-10. [CrossRef]

Jamali, Dima, and Charlotte Karam. 2018. Corporate social responsibility in developing countries as an emerging field of study. The International Journal of Management Reviews 20: 32-61. [CrossRef]

Jensen, Michael C., and William H. Meckling. 1976. Theory of the firm: Managerial behavior, agency costs and ownership structure. Journal of Financial Economics 3: 305-60. [CrossRef]

Kale, Jayant R., and Husayn Shahrur. 2007. Corporate capital structure and the characteristics of suppliers and customers. Journal of Financial Economics 83: 321-65. [CrossRef]

Keramati, Abbas, Hamed Mehrabi, and Navid Mojir. 2010. A process-oriented perspective on customer relationship management and organizational performance: An empirical investigation. Industrial Marketing Management 39: 1170-185. [CrossRef]

Khandwalla, Pradip N. 1976. The techno-economic ecology of corporate strategy. Journal of Management Studies 13: 62-75. [CrossRef]

Khatri, Naresh, and Brian D'Netto. 1997. Perceived uncertainty and performance: The causal direction. Journal of Applied Management Studies 6: 219-233. 
Kline, Rex B. 2005. Principles and Practice of Structural Equation Modeling, 2nd ed. New York: Guilford Press.

Lawrence, Paul R., and Jay W. Lorsch. 1967. Organization and Environment. Boston: Harvard Business School, Division of Research.

Levy, Amnon, and Christopher Hennessy. 2007. Why does capital structure choice vary with macroeconomic conditions? Journal of Monetary Economics 54: 1545-64. [CrossRef]

Lorca, Pedro, and Julita García-Diez. 2004. The relation between firm survival and the achievement of balance among its stakeholders: An analysis. International Journal of Management 21: 93-99.

MacKie-Mason, Jeffrey K. 1990. Do taxes affect corporate financing decisions? Journal of Finance 45: 1471-93. [CrossRef]

Margaritis, Dimitris, and Maria Psillaki. 2010. Capital structure, equity ownership and firm performance. Journal of Banking \& Finance 34: 621-32. [CrossRef]

McCaffery, Kate, Robert Hutchinson, and Robert Jackson. 1997. Aspects of the finance function: A review and survey into the UK retailing sector. International Review of Retail, Distribution and Consumer Research 7: 125-44. [CrossRef]

Mitchell, Ronald K., Bradley R. Agle, and Donna J. Wood. 1997. Toward a theory of stakeholder identification and salience: Defining the principle of who and what really counts. Academy of Management Review 22: 853-86. [CrossRef]

Modigliani, Franco, and Merton H. Miller. 1958. The cost of capital, corporation finance and the theory of investment. The American Economic Review 48: 261-97.

Modigliani, Franco, and Merton H. Miller. 1963. Corporate income taxes and the cost of capital: A correction. The American Economic Review 53: 433-43.

Myers, Stewart C. 1984. The capital structure puzzle. The Journal of Finance 39: 574-92. [CrossRef]

Ntim, Collins G., and Teerooven Soobaroyen. 2013. Corporate governance and performance in socially responsible corporations: New empirical insights from a Neo-Institutional framework. Corporate Governance: An International Review 21: 468-94. [CrossRef]

Post, James E., Lee E. Preston, and Sybille Sauter-Sachs. 2002. Redefining the Corporation: Stakeholder Management and Organizational Wealth. Stanford: Stanford University Press.

Preston, Lee E., and Douglas P. O'Bannon. 1997. The corporate social-financial performance relationship: A typology and analysis. Business and Society 36: 419-29. [CrossRef]

Raman, Kartik, and Husayn Shahrur. 2008. Relationship-specific investments and earnings management: Evidence on corporate suppliers and customers. Accounting Review 83: 1041-81. [CrossRef]

Rashid, Abdul. 2013. Risks and financing decisions in the energy sector: An empirical investigation using firm-level data. Energy Policy 59: 792-99. [CrossRef]

Schulz, Axel K. D., Anne Wu, and Chee W. Chow. 2010. Environmental uncertainty, comprehensive performance measurement systems, performance-based compensation, and organizational performance. Asia-Pacific Journal of Accounting E Economics 17: 17-39. [CrossRef]

Sen, Sankar, Chitra Bhanu Bhattacharya, and Daniel Korschun. 2006. The role of corporate social responsibility in strengthening multiple stakeholder relationships: A field experiment. Journal of the Academy of Marketing Science 34: 158-66. [CrossRef]

Sharfman, Mark P., and Chitru S. Fernando. 2008. Environmental risk management and the cost of capital. Strategic Management Journal 29: 569-92. [CrossRef]

Steenkamp, Jan-Benedict E. M., and Hans Baumgartner. 2000. On the use of structural equation models for marketing modeling. International Journal of Research in Marketing 17: 195-202. [CrossRef]

Suchman, Mark C. 1995. Managing legitimacy: Strategic and institutional approaches. Academy of Management Review 20: 571-610. [CrossRef]

Swamidass, Paul M., and William T. Newell. 1987. Manufacturing strategy, environmental uncertainty and performance: A path analytic model. Management Science 33: 509-24. [CrossRef]

Titman, Sheridan. 1984. The effect of capital structure on a firm's liquidation decision. Journal of Financial Economics 13: 137-51. [CrossRef]

Titman, Sheridan, and Roberto Wessels. 1988. The determinants of capital structure choice. Journal of Finance 43: 1-19. [CrossRef]

Tyagi, Rupal. 2012. The Impact of Corporate Social Responsibility on Financial Performance and Competitiveness of Business: A Study of Indian Firms. Ph.D. dissertation, Indian Institute of Technology, Roorkee, India. 
Verbeeten, Frank H. M. 2006. Do organizations adopt sophisticated capital budgeting practices to deal with uncertainty in the investment decision? A research note. Management Accounting Research 17: 106-20. [CrossRef]

Verwijmeren, Patrick, and Jeroen Derwall. 2010. Employee well-being, firm leverage, and bankruptcy risk. Journal of Banking \& Finance 34: 956-64. [CrossRef]

Welch, Ivo. 2004. Capital structure and stock returns. Journal of Political Economy 112: 106-31. [CrossRef]

(C) 2020 by the authors. Licensee MDPI, Basel, Switzerland. This article is an open access article distributed under the terms and conditions of the Creative Commons Attribution (CC BY) license (http://creativecommons.org/licenses/by/4.0/). 